\title{
Helium-3 in the Guaymas Basin: Evidence for Injection of Mantle Volatiles in the Gulf of California
}

\author{
JOHN E. LUPTON
}

\author{
Scripps Institutıon of Oceanography, University of California at San Diego, La Jolla, California 92093
}

\begin{abstract}
Helium isotope measurements in six major basins in the Gulf of California show that the doep Guaymas Basin has ${ }^{3} \mathrm{He} /{ }^{4} \mathrm{He} 65-70 \%$ higher than atmospheric helium, clear evidence of mantle helium injection. Smaller ${ }^{3} \mathrm{He}$ excesses observed in the Carmen and Farallon basins may be derived from this Guaymas Basin anomaly. The ${ }^{3} \mathrm{He}$ concentrations in the Mazatlan Basin in the mouth of the Gulf of California are similar to average eastern Pacific values, indicating that the Gulf does not provide a significant flux of ${ }^{3} \mathrm{He}$ into the general Pacific circulation. On the basis of temperalure and salinity measurements an upper limit of $0.28^{\circ} \mathrm{C}$ can be placed on the amount of geothermal heating observed in any of the basins. The isolopic ratio of the injected Guaymas Basin helium is found to be ${ }^{3} \mathrm{He} /{ }^{4} \mathrm{He}=(1.10 \pm 0.06) \times 10^{-5}$, almost identical to the helium signalure observed at the Galapagos Rift but somewhat lower than the average ratio in oceanic basalt glasses.
\end{abstract}

\section{INTRODUCTION}

It is now generally accepted that the Gulf of California is the result of tectonic activity along a series of spreading centers and transform faults which link the East Pacific Rise to the south with the San Andreas system to the north. Thus the Gulf is bisected by the junction between the Pacific and North American plates, and it has been the subject of many investigations describing its bathymetry, hydrography, and geology [Roden, 1964; Larson et al., 1968, 1972]. In particular, the bathymetry is characterized by a series of deep basins which coincide with and are thought to be produced by the zones of spreading activity.

Scripps Institution of Oceanography's (SIO) Expedition Hypogene was an extension of these previous studies and a search for hydrothermal features and metalliferous sediments in the basins of the Gulf. Although no hydrothermal features were discovered [Wilde et al., 1973], heat flow measurements gave high and irregular heat fluxes in the Guaymas and Farallon basins [Lawver et al., 1973]. When combined with earlier results [Von Herzen, 1963], these data were interpreted as evidence for recent active intrusion coupled with hydrothermal circulation. A subsequent more detailed study of the Guaymas Basin yielded even higher heat flow values, leading these authors to conclude that the Guaymas Basin should be given serious consideration as a geothermal resource [Lawver et al., 1975].

Numerous studies have shown that ${ }^{3} \mathrm{He}$ is an extremely sensitive geochemical tracer for detecting mantle-derived volatiles at major oceanic spreading centers (Lupton and Craig, 1975; Craig and Lupton, 1976], at subduction zones [Craig et al., 1978a], and at several hot spots [Craig and Lupton, 1976; Craig et al., 1978b; Polak et al., 1976]. Mantle helium is apparently characterized by ${ }^{3} \mathrm{He} /{ }^{4} \mathrm{He}$ ratios about $10-20$ times the atmospheric ratio. The Red Sea Brines, for example, are 300 times enriched in helium relative to air saturation with a ${ }^{3} \mathrm{He} /{ }^{4} \mathrm{He}$ ratio 8.6 times atmospheric [Lupton et al., 1977a]. At the Galapagos Rift, actual hydrothermal vents were found for the first time in the open ocean using the Deep-Tow vehicle of the SIO Marine Physical Laboratory [Weiss et al., 1977; Lupton et al., 1977b]. This initial survey was followed by detailed submersible exploration of the hydrothermal systems in this area [Jenkins et al., 1978]. These Galapagos vents discharge water of normal salinity containing excess helium with ${ }^{3} \mathrm{He} /{ }^{4} \mathrm{He}=7.8 \times\left({ }^{3} \mathrm{He} /{ }^{4} \mathrm{He}\right)$ arr, showing that spreading center hydrothermal systems need not involve the high salt enrichments which result in stable brine pools such as those found in the Red Sea.

In this context, the Gulf of California is an ideal location for detailed helium isotope mapping. The highest open ocean ${ }^{3} \mathrm{He}$ concentrations are found in the deep eastern Pacific, indicating

Copyright 1979 by the American Geophysical Union. that a significant flux of ${ }^{3} \mathrm{He}$ is being injected into the Pacific circulation by the spreading activity of the East Pacific Rise system [Clarke et al., 1969, 1970; Craig et al., 1975]. In the Gulf of California, helium injection at spreading centers should produce even higher concentrations because of the confined geometry of the basins. In this paper I present the results of an initial survey of ${ }^{3} \mathrm{He},{ }^{4} \mathrm{He}$, and neon concentrations in six basins of the Gulf, using water samples collected during leg 2 of Hypogene Expedition (1972) and leg 6 of F Drake 77 Expedition.

\section{ANALyTiCal Methods}

Water samples for dissolved gas analysis were collected in Niskin hydrographic bottles and immediately sealed into $40 \mathrm{cc}$ copper tubing samplers. The gases were later extracted in a high-vacuum line, split into known fractions using a calibrated gas splitter, and sealed into 1720 glass breakseal tubes. The extraction procedure [Lupton, 1976] yields $>99.9 \%$ of the $\mathrm{He}$, $\mathrm{Ne}$, and $\mathrm{Ar}$ in the sample. The system blank is $\sim 10^{-9} \mathrm{cc}$ of $\mathrm{He}$, which is $<0.1 \%$ of the sample.

${ }^{3} \mathrm{He} /{ }^{4} \mathrm{He}$ ratios were measured on a $25-\mathrm{cm}$ radius, dualcollector ${ }^{3} \mathrm{He}$ mass spectrometer [Lupton and Craig, 1975; Craig and Lupton, 1976]. The isotope measurements were standardized by analyzing air aliquots and assuming $\left({ }^{3} \mathrm{He} /{ }^{4} \mathrm{He}\right)_{a, r}=1.4 \times 10^{-6}$. The average spectrometer precision of $1 \sigma$ is $0.7 \%$.

For the Guaymas and Mazatlan basin samples (stations H29 and FD4), breakseal splits were analyzed for absolute helium and neon amounts on a separate rare gas spectrometer by isotope dilution. With this method, samples are spiked with known amounts of ${ }^{3} \mathrm{He}$ and ${ }^{22} \mathrm{Ne}$, and measurements of the ${ }^{3} \mathrm{He} /{ }^{4} \mathrm{He}$ and ${ }^{20} \mathrm{Ne} /{ }^{22} \mathrm{Ne}$ ratios of the mixture then give the absolute $\mathrm{He}$ and $\mathrm{Ne}$ amounts for the sample. The internal precision for both $\mathrm{He}$ and $\mathrm{Ne}$ is $\sim 0.3 \%$, which is considerably better than the peak height method. The error is somewhat higher when uncertainties in the sample weight and gas-splitting procedure are included. However, values for the $\mathrm{He} / \mathrm{Ne}$ ratio, which are immune to errors in sample weight, etc., are accurate to $\sim 0.3 \%$.

A certain fraction of the copper tubing samplers develops leaks when stored for several years before extraction [Lupton, 1976]. The average storage time in the copper tubes was 4.7 years for the Hypogene samples, and some samples were indeed lost. Because of the long storage time and because the Hypogene work was one of the first trials at sea with copper tubing samplers, the possibility of leakage musi be considered even for apparently valid samples. The Hypogene ${ }^{3} \mathrm{He} /{ }^{4} \mathrm{He}$ values should thus bc assigned errors of about $5 \%$, even though the analytical precision is much higher. The F Drake 77 Expedition samples were storcil only 135 days before extraction, so that the leakage problem doc not affect these data in any way. 


\section{RESULTS AND DISCUSSION}

The station locations are summarized in Table 1. Eight hydrographic stations were occupied during Hypogene Expedition, and samples were collected for helium analysis at five of these (H20, $\mathrm{H} 29, \mathrm{H} 37, \mathrm{H} 44$, and H51). On F Drake 77 Expedition samples were collected at station FD4 in order to extend this section into normal Pacific water outside the Gulf. As shown in Figure 1, these six stations provide a sampling of the water column in each of the major basins in the Gulf of California.

\section{${ }^{3} \mathrm{He} /{ }^{4} \mathrm{He}$ Results}

The ${ }^{3} \mathrm{He} /{ }^{4} \mathrm{He}$ results are shown in Figure 2, in which $\delta\left({ }^{3} \mathrm{He}\right)$, the percentage deviation of ${ }^{3} \mathrm{He} /{ }^{4} \mathrm{He}$ from the ratio in air, is plotted versus depth for all stations. The isotopic and isotopedilution concentration measurements made on samples from stations $\mathrm{H} 29$ and FD4 are listed in Table 2 . All $\delta\left({ }^{3} \mathrm{He}\right)$ values have been corrected for the increase of ${ }^{3} \mathrm{He}$ due to tritium decay during sample storage to give corrected values which represent the actual ${ }^{3} \mathrm{He} /{ }^{4} \mathrm{He}$ ratio in the sample at the time of collection. These tritium corrections are significant only at depths of less than $1000 \mathrm{~m}$; they were made by assuming that the tritium profile at station H29 (Table 2) is representative of the tritium distribution throughout the Gulf. With the exception of the near-surface sample, these Guaymas Basin tritium results were measured in the laboratory at SIO by the ${ }^{3} \mathrm{He}$ regrowth method [Clarke et al., 1976]. The shallowest of these samples was lost by leakage, and the surface tritium value at station $\mathrm{H} 29$ was estimated using tritium concentrations measured at San Felipe and at Concepcion Bay ( $R$. Michel, personal communication, 1978). In every case the difference between the observed and corrected $\delta\left({ }^{3} \mathrm{He}\right)$ values is $<5 \%$. The hydrographic and dissolved gas data for all of the Gulf of California stations discussed here are on file at the Physical and Chemical Oceanographic Data (formerly GEOSECS Operations Group) Facility of the Scripps Institution of Oceanography.

Although rather large errors are associated with most of these ${ }^{3} \mathrm{He}$ results, the profiles in Figure 2 show a very clear ${ }^{3} \mathrm{He}$ excess in several of the basins. Station FD4 in the Mazatlan Basin, collected to provide an open-ocean boundary profile, has a maximum $\delta\left({ }^{3} \mathrm{He}\right)=3: 4 \%$ at $2500 \mathrm{~m}$ depth and is essentially identical to other profiles measured in the eastern equatorial Pacific [Craig et al., 1975]. This represents the regional ${ }^{3} \mathrm{He}$ excess due to the injection of primordial helium associated with the general spreading center activity in the eastern Pacific, and thus the input water from the eastern Pacific into the Gulf. Using this Mazatlan Basin profile as a baseline, the Guaymas, Carmen, and Farallon basins all show clear enrichments of ${ }^{3} \mathrm{He}$, the S. Pescadero Basin profile is very close to the ambient level, and the Sal Si Puedes Basin is actually deficient in ${ }^{3} \mathrm{He}$.

The Guaymas Basin profile (station H29) confirms the expec-

TABLE 1. Hydrographic Stations in the Gulf of California

\begin{tabular}{|c|c|c|c|c|}
\hline $\begin{array}{l}\text { Expedition/ } \\
\text { Station No.* }\end{array}$ & Basin & Latitude & Longitude & $\begin{array}{l}\text { Depth, } \\
\text { m }\end{array}$ \\
\hline $\mathrm{H} 20 \dagger$ & Sal Si Puedes & $28^{\circ} 42.4^{\prime} \mathrm{N}$ & $113^{\circ} 00.3^{\prime} \mathrm{W}$ & 1588 \\
\hline $\mathrm{H} 29 \dagger$ & Guaymas & $27^{\circ} 23.7^{\prime} \mathrm{N}$ & $111^{\circ} 26.4^{\prime} \mathrm{W}$ & 2043 \\
\hline H32 & Guaymas & $26^{\circ} 59.8^{\prime} \mathrm{N}$ & $111^{\circ} 24.6^{\circ} \mathrm{W}$ & 2012 \\
\hline $\mathrm{H} 37 \dagger$ & Carmen & $26^{\circ} 46.8^{\prime} \mathrm{N}$ & $110^{\circ} 55.7^{\prime} \mathrm{W}$ & 2788 \\
\hline $\mathrm{H} 41$ & Farallon & $25^{\circ} 35.6^{\prime} \mathrm{N}$ & $109^{\circ} 46.7^{\circ} \mathrm{W}$ & 3185 \\
\hline $\mathrm{H} 44 \dagger$ & Farallon & $25^{\circ} 31.7^{\prime} \mathrm{N}$ & $109^{\circ} 50.6^{\circ} \mathrm{W}$ & 3229 \\
\hline H48 & Pescadero & $24^{\circ} 41.7^{\prime} \mathrm{N}$ & $109^{\circ} 08.6^{\prime} \mathrm{W}$ & 3326 \\
\hline $\mathrm{H} 51 \dagger$ & Pescadero & $23^{\circ} 58.7^{\prime} \mathrm{N}$ & $108^{\circ} 50.3^{\prime} \mathrm{W}$ & 3784 \\
\hline FD4† & Mazatlan & $22^{\circ} 56.0^{\prime} \mathrm{N}$ & $108^{\circ} 05.9^{\prime} \mathrm{W}$ & 3435 \\
\hline
\end{tabular}

${ }^{*} \mathrm{H}$ denotes Hypogene Expedition and FD denotes F Drake 77. †Helium analyzed. tation that helium injection associated with spreading center activity should cause elevated ${ }^{3} \mathrm{He} /{ }^{4} \mathrm{He}$ ratios within the confined geometry of the Gulf of California. With the exception of the actual hydrothermal emanations sampled in the Galapagos Rift [Weiss et al., 1977; Lupton et al., 1977b; Jenkins et al., 1978], the very high helium isotope enrichments in the Guaymas Basin of $\delta\left({ }^{3} \mathrm{He}\right)=68 \%$ at $1600-1900 \mathrm{~m}$ depth are the highest ${ }^{3} \mathrm{He} /{ }^{4} \mathrm{He}$ ratios so far reported for seawater samples. Specifically, this water contains helium with ${ }^{3} \mathrm{He} /{ }^{4} \mathrm{He}$ about $30 \%$ higher than normal deep Pacific water at this depth, suggesting that hydrothermal circulation exists up to the sediment-water interface.

What fraction, if any, of the excess ${ }^{3} \mathrm{He}$ in the Gulf can be attributed to in situ tritium decay? In the northern hemisphere most of the oceanic tritium is the product of thermonuclear testing conducted in 1961 and 1962 [Fine and Östlund, 1977]. The natural steady-state tritium levels due to cosmic ray production are estimated at $0.2-0.6 \mathrm{TU}$ for surface seawater [Craig and Lal, 1961]. Thus the concentrations of $3-8$ TU observed in the surface waters of the Gulf ( $R$. Michel, personal communication, 1978) are due to bomb-tritium; and as indicated by the Guaymas

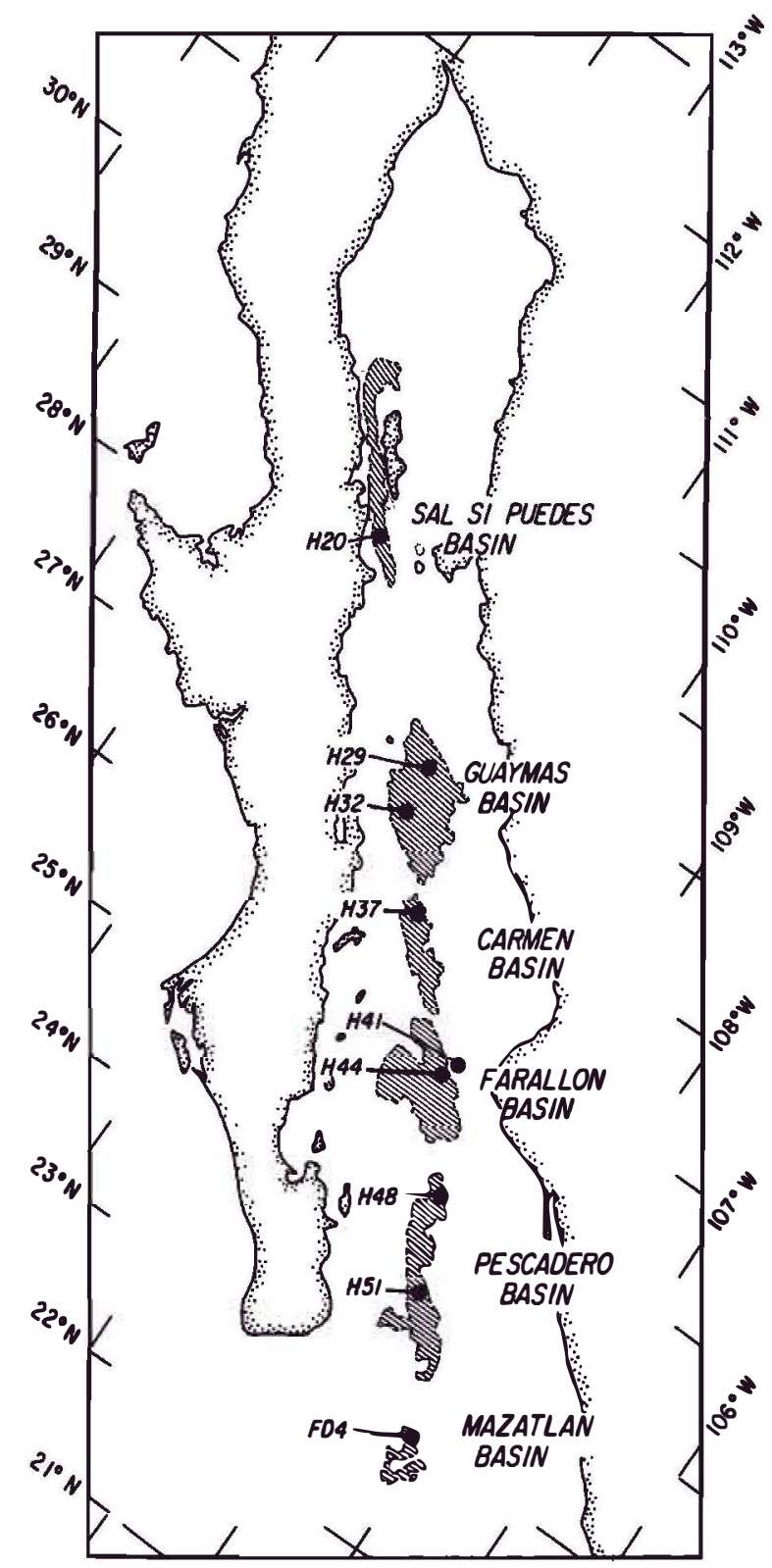

Fig. 1. Location of hydrographic stations in the Gulf of California (H: Hypogene Expedition; FD: F Drake 77). Shading indicates the approximate extent of the six major basins. 
TABLE 2. Tritium, Helium, and Neon Data for the Guaymas and Mazatlan Basins, Gulf of California

\begin{tabular}{|c|c|c|c|c|}
\hline $\begin{array}{l}\text { Depth, } \\
\text { m }\end{array}$ & $\begin{array}{c}\text { Tritium,* } \\
\text { TU }\end{array}$ & $\delta\left({ }^{3} \mathrm{He}\right), \%$ & $\Delta\left({ }^{3} \mathrm{He} / \mathrm{Ne}\right), \%$ & $\Delta\left({ }^{4} \mathrm{He} / \mathrm{Ne}\right), \%$ \\
\hline \multicolumn{5}{|c|}{ H29 Guaymas Basin } \\
\hline 16 & $(4.3) \dagger$ & $-1.4 \ddagger$ & 0.9 & 0.9 \\
\hline 305 & 0.74 & $4.8 \ddagger$ & 7.7 & 1.3 \\
\hline 811 & 0.31 & $16.3 \ddagger$ & 22.1 & 3.5 \\
\hline 1115 & $<0.06$ & 27.0 & 35.7 & 5.3 \\
\hline 1421 & $\ldots$ & 43.7 & 56.6 & 7.5 \\
\hline 1696 & $<0.06$ & 66.8 & $\ldots$ & $\ldots$ \\
\hline 1934 & $\ldots$ & 68.3 & 91.9 & 12.4 \\
\hline \multicolumn{5}{|c|}{ FD4 Mazallan Basin } \\
\hline 0 & $\ldots$ & $-1.1 \neq$ & 0.7 & 0.4 \\
\hline 803 & $\ldots$ & 15.2 & 20.9 & 3.5 \\
\hline 1007 & $\ldots$ & 19.8 & 26.8 & 4.4 \\
\hline 1210 & $\ldots$ & 22.0 & $\ldots$ & $\ldots$ \\
\hline 1413 & $\cdots$ & 23.8 & 32.7 & $\dddot{5.7}$ \\
\hline 1615 & $\cdots$ & 28.0 & 36.8 & 5.4 \\
\hline 1818 & $\cdots$ & 29.3 & 38.9 & 5.9 \\
\hline 2020 & $\cdots$ & 30.2 & 40.9 & 6.7 \\
\hline 2223 & $\cdots$ & 32.8 & 43.4 & 6.5 \\
\hline 2427 & $\ldots$ & 33.9 & 44.9 & 6.7 \\
\hline 2529 & … & 33.8 & 44.4 & 6.4 \\
\hline 2631 & $\cdots$ & 32.8 & 43.0 & 6.2 \\
\hline 2734 & $\begin{array}{l}\cdots \\
\ldots\end{array}$ & 31.7 & 41.6 & 6.0 \\
\hline 2837 & $\begin{array}{l}\cdots \\
\ldots\end{array}$ & 30.9 & 41.3 & 6.4 \\
\hline 2940 & $\ldots$ & 28.4 & 38.4 & 6.3 \\
\hline 3043 & $\ldots$ & 29.4 & 38.5 & 5.5 \\
\hline 3251 & $\ldots$ & 27.6 & 36.4 & 5.4 \\
\hline 3351 & $\ldots$ & 25.6 & 34.5 & 5.6 \\
\hline
\end{tabular}

The $1 \sigma$ error in the analytical precision is $0.7 \%$ for $\delta\left({ }^{3} \mathrm{He}\right)$ and $0.3 \%$ for $\Delta\left({ }^{3} \mathrm{He} / \mathrm{Ne}\right)$ and $\Delta\left({ }^{4} \mathrm{He} / \mathrm{Ne}\right)$. See text for discussion of the errors.

${ }^{*}$ Measured at SIO by the mass spectrometer regrowth method; $1 \mathrm{TU}=10^{18} \mathrm{x}$ mole fraction of $\left({ }^{3} \mathrm{H} /{ }^{\prime} \mathrm{H}\right)$.

†Surface tritium sample leaked. This value was estimated from other Gulf of California data (R. Michel, personal communication, 1978).

$¥$ These values were corrected for ${ }^{3} \mathrm{He}$ increase due to tritium decay during storage. Tritium for Mazatlan Basin is assumed to be identical to the Guaymas Basin profile. The corrections to $\delta\left({ }^{3} \mathrm{He}\right)$ were respectively $4.5 \%, 0.7 \%$, and $0.3 \%$ for the samples at 16,305 , and $811 \mathrm{~m}$ depth in the Guaymas Basin and $0.4 \%$ for the surface sample in the Mazatlan Basin.

Basin profile (Table 2), this artificial tritium has not penetrated below $1000 \mathrm{~m}$. It is reasonable to assume that the vertical distribution of tritium at other locations in the Gulf is very similar to the Guaymas Basin profile. The contribution to ${ }^{3} \mathrm{He}$ by tritium decay at depths below $1000 \mathrm{~m}$ can be estimated by assuming that the upper limit of $0.06 \mathrm{TU}$ (Table 2) observed in 1972 is a 10year-old remnant of bomb-tritium injected in the early 1960's. This requires an initial tritium concentration of $0.1 \mathrm{TU}$ and gives $0.2 \%$ as the change in $\delta\left({ }^{3} \mathrm{He}\right)$ due to tritium decay. Alternatively, one can consider the unlikely possibility that the deep water initially contained $\sim 0.5 \mathrm{TU}$ of natural tritium. A period of 38 years would be required for this to decay to the observed $0.06 \mathrm{TU}$ level, producing a $2 \%$ increase in $\delta\left({ }^{3} \mathrm{He}\right)$. Finally, the effect of Colorado River water, with an estimated pre-bomb tritium content of $\sim 5$ TU [Kaufman and Libby, 1954; von Buttlar and Libby, 1955], can also be neglected, since a simple calculation based on salinity shows that the deep waters of the Gulf cannot contain more than a few percent of this river water. Some insight into the overall effect of tritium decay on the ${ }^{3} \mathrm{He}$ in the Gulf can be gained by comparison with open-ocean observations at similar latitudes. In the North Atlantic, where the primordial helium input can be neglected in the shallow waters, ${ }^{3} \mathrm{He} /{ }^{4} \mathrm{He}$ profiles at $20^{\circ}$ to $30^{\circ} \mathrm{N}$ latitude show a peak at $\sim 500 \mathrm{~m}$ which can be clearly attributed to tritium decay [Jenkins and Clarke, 1976; Lupton, 1976]. This peak averages $\delta\left({ }^{3} \mathrm{He}\right)=6$ $8 \%$ at the maximum, with no evidence for radiogenic ${ }^{3} \mathrm{He}$ input below $1000 \mathrm{~m}$ depth. In summary, one can conclude that tritium decay may have elevated $\delta\left({ }^{3} \mathrm{He}\right)$ by $\sim 5 \%$ in the shallow waters of the Gulf, but for the deep water this effect is certainly $<2 \%$ and probably negligible.

Bathymetry in the Gulf has a strong effect on the helium distribution. In Figure $3, \delta\left({ }^{3} \mathrm{He}\right)$ is contoured in a section through the major basins, showing that the Guaymas is the only basin in which $\delta\left({ }^{3} \mathrm{He}\right)$ increases significantly below the sill depth, indicating a flux of ${ }^{3} \mathrm{He}$ out of the basin. This is not the case for the Carmen and Farallon basins, and it is quite possible that the ${ }^{3} \mathrm{He}$ enrichment observed in these basins is due to overflow from the Guaymas Basin. This section also indicates that there is no input of anomalous helium into the Sal Si Puedes Basin and that the deep water in this basin with $\delta\left({ }^{3} \mathrm{He}\right)=10 \%$ is supplied entirely by flow over the sill at $500 \mathrm{~m}$ depth. In the same way, the deep water in the S. Pescadero Basin could be derived from an input of ambient Pacific deep water over the sill at $\sim 2500 \mathrm{~m}$ without invoking any supply of primordial helium within the basin itself.

From the standpoint of using ${ }^{3} \mathrm{He}$ as an oceanographic tracer it is important to determine whether the Gulf of California provides a significant input of ${ }^{3} \mathrm{He}$ into the deep Pacific circulation. Although there is an obvious ${ }^{3} \mathrm{He}$ source in the Guaymas Basin in the central Gulf, the lack of any significant lateral gradient in $\delta\left({ }^{3} \mathrm{He}\right)$ in the southern end of the Gulf indicates that any flux of ${ }^{3} \mathrm{He}$ from the Gulf is not significant compared to other sources in the eastern Pacific. (This conclusion could be altered in the 


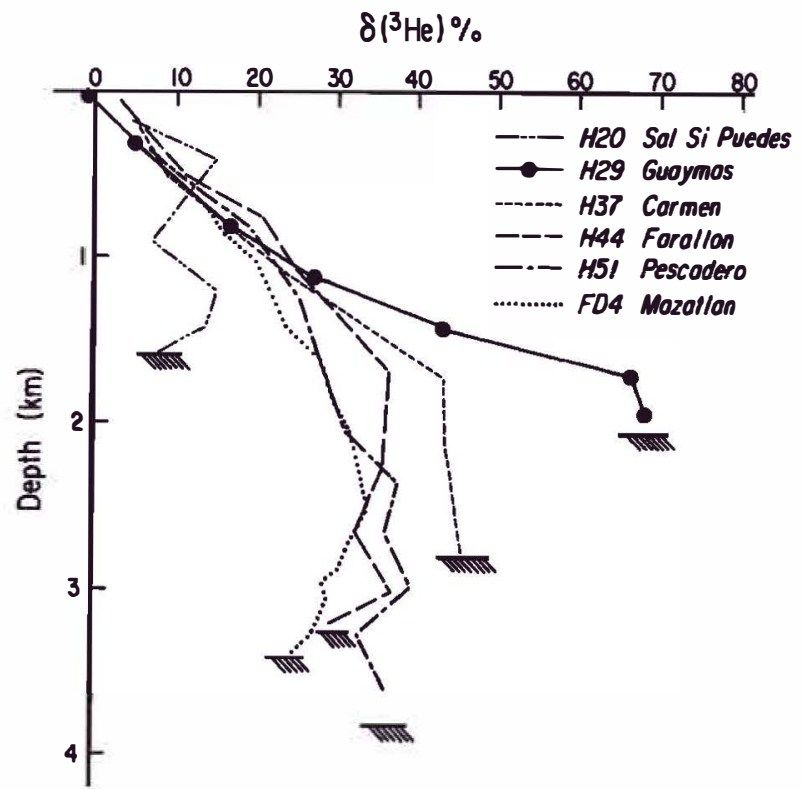

Fig. 2. The $\delta\left({ }^{3} \mathrm{He}\right)$ profiles in the Gulf of California. The profiles are corrected for ${ }^{3} \mathrm{He}$ formed by tritium decay during sample storage.

unlikely possibility that some ${ }^{3} \mathrm{He}$-rich water leaves the Gulf by a route completely isolated from the Mazatlan Basin profile.)

\section{Bathymetry and Temperature Relationships}

One of the major findings of Hypogene Expedition was to deny the existence of hot brines in the major basins of the Gulf of California [Wilde et al., 1973]. In the light of the large ${ }^{3} \mathrm{He}$ excesses reported here and considering the recent discovery in the Galapagos Rift of ${ }^{3} \mathrm{He}$-rich hydrothermal fluids with normal salinity [Weiss et al., 1977; Lupton et al., 1977b; Jenkins, 1978], it seems appropriate to take a closer look at the Hypogene hydrographic data in an attempt to delineate possible temperature anomalies.

The relationship between temperature and bathymetry is shown in Figure 4, in which the Hypogene and F Drake 77 potential temperature data are contoured in a section through the axis of the Gulf. The figure shows that the deep water is approximately isothermal within each basin but varies considerably from basin to basin at the same depth. To first order these deep-basin temperatures are controlled by the sill depth for each basin. The fact that deep Guaymas Basin water is $-0.3^{\circ} \mathrm{C}$ warmer than Carmen Basin water at the same depth is due largely to this sill effect, and additional tracers are required to determine whether any geothermal heating has occurred.

The Galapagos Deep-Tow investigations [Weiss et al., 1977] showed that a very sensitive method for detecting small temperature anomalies is to first carefully define the potential temperature versus salinity relationship for a given region and then to search for deviations from this relationship. This technique serves to remove the effects of mixing which can result in water masses of different temperature at the same depth without any addition of heat. In Figure 5, potential temperature is plotted versus salinity for eight stations in the Gulf. These data fall within a linear band with a width of $0.28^{\circ} \mathrm{C}$ in potential temperature (or $0.025 \%$ in salinity). Within this band there is no correlation of the potential temperature with ${ }^{3} \mathrm{He}$ excess, as one might expect if hydrothermal processes are important. In fact, the deep Guaymas Basin samples which exhibit the highest ${ }^{3} \mathrm{He} /{ }^{4} \mathrm{He}$ ratios have potential temperatures somewhat lower than the mean. This scatter, which is probably due to salinometer drift, means that one can only place an upper limit of about $0.28^{\circ} \mathrm{C}$ for the temperature increase due to geothermal heating in the basins of

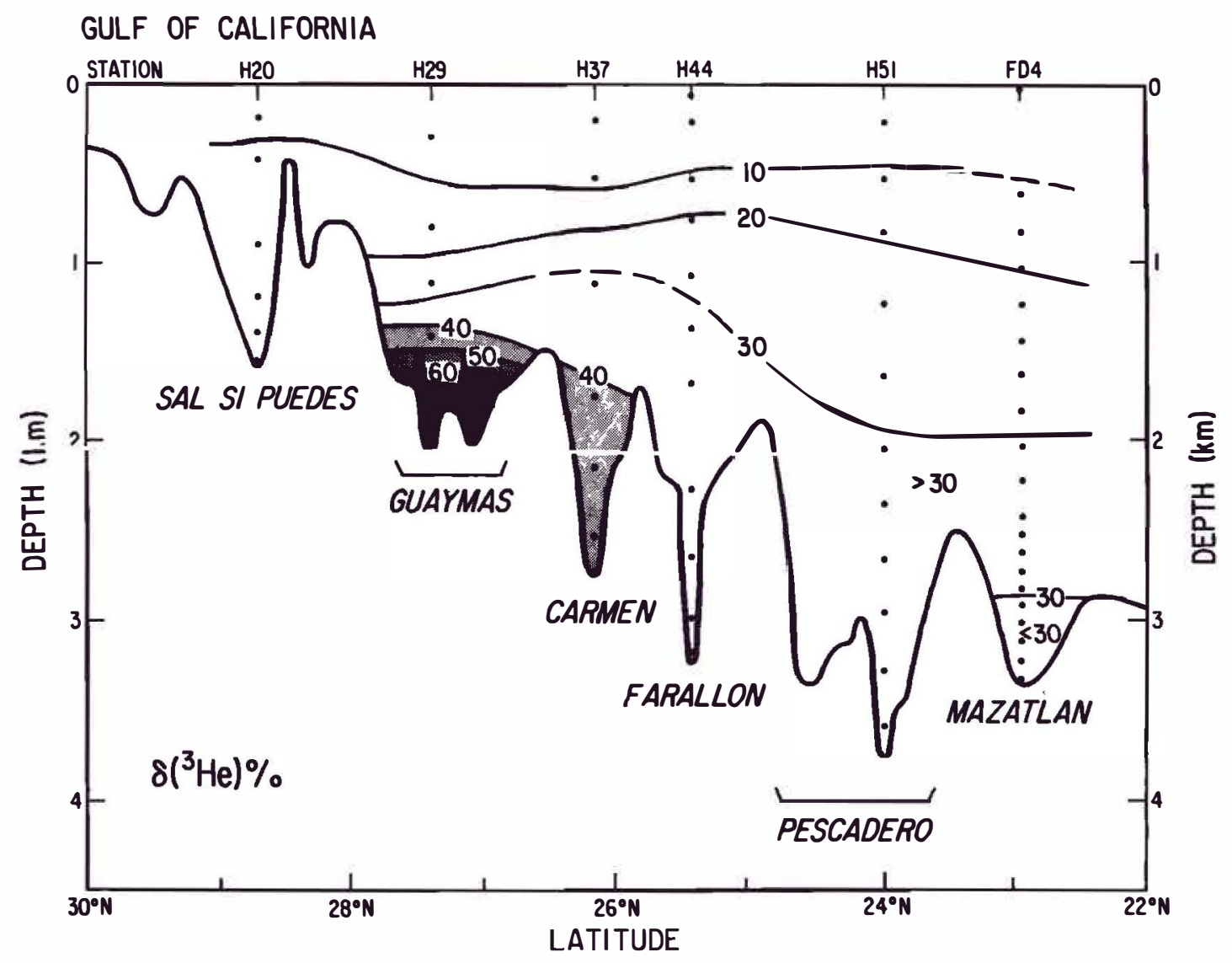

Fig. 3. A $\delta\left({ }^{3} \mathrm{He}\right)$ section from NW to SE through the major basins of the Gulf. Bathymetry is from Fisher et al. [1964]. 


\section{GULF OF CALIFORNIA}

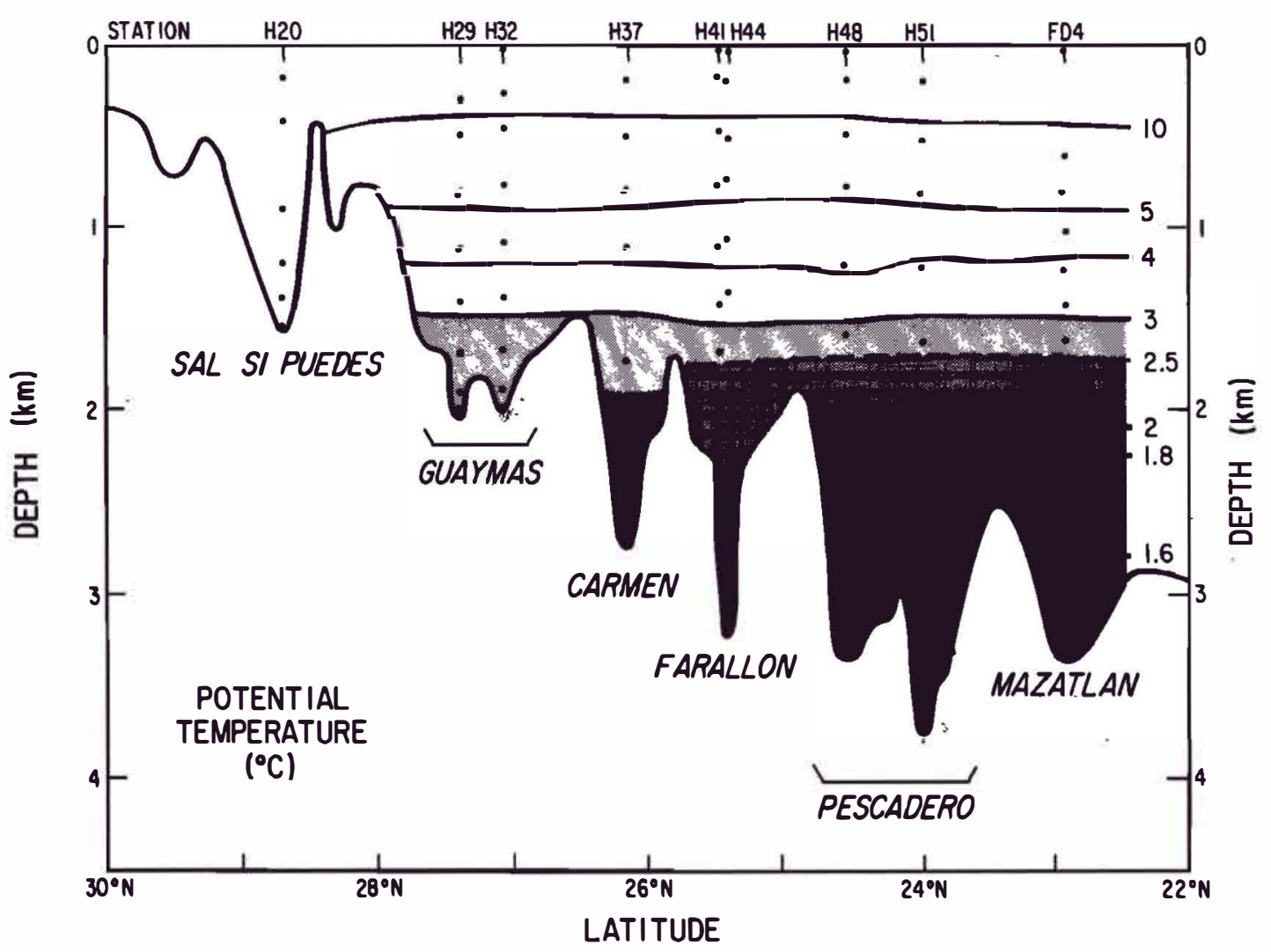

Fig. 4. Potential temperature section from NW to SE through the major basins of the Gulf.

the Gulf. It should be noted that Wilde et al. [1973] reached a similar conclusion on the basis of the Hypogene temperature data alone.

What magnitude of temperature anomaly would be expected in the deep Guaymas Basin based on previous experience with the Galapagos hydrothermal fluids and with the Red Sea brines? For these two examples the ratio of heat $/{ }^{3} \mathrm{He}$ falls in the range of $2-8$ $\times 10^{-8} \mathrm{cal} /$ atom of ${ }^{3} \mathrm{He}\left(6-21 \times 10^{110} \mathrm{C}-\mathrm{g} / \mathrm{cm}^{3}\right.$ STP $\left.{ }^{3} \mathrm{He}\right)$. The deep Guaymas Basin contains $5 \times 10^{-14} \mathrm{~cm}^{3} \mathrm{STP} / \mathrm{g}$ of ${ }^{3} \mathrm{He}$ in excess of solubility $\left(1.4 \times 10^{6}\right.$ atoms $\left.{ }^{3} \mathrm{He} / \mathrm{g}\right)$, yielding an expected temperature anomaly of $0.03-0.10^{\circ} \mathrm{C}$. This is too small to be detected using the Hypogene hydrographic data (Figure 5). However, careful measurements to $\pm 0.001 \%$ in salinity in each of the basins of the Gulf would allow heating effects as small as $0.01^{\circ} \mathrm{C}$ to be detected as deviations from the T-S relationship.

\section{ISOTOPIC RATIO OF THE INJECTED HELIUM}

Previous isotopic measurements of mantle derived helium have yielded ${ }^{3} \mathrm{He} /{ }^{4} \mathrm{He}$ values ranging from $9 \times 10^{-6}$ for convergent plate boundaries [Craig et al., 1978a] up to $2.2 \times 10^{-5}$ for hot spots such as Kilauea [Craig and Lupton, 1976], Yellowstone National Park [Craig et al., 1978b] and Iceland [Polak et al., 1976]. In particular, the ${ }^{3} \mathrm{He} /{ }^{4} \mathrm{He}$ ratio in midocean ridge basalt glasses varies from $1.2 \times 10^{-5}$ to $1.7 \times 10^{-5}$, averaging $1.4 \times$ $10^{-5}$, or about 10 times the atmospheric ratio [Lupton and Craig, 1975; Craig and Lupton, 1976]. In this context the determination of the isotopic ratio of the helium actually injected into the Guaymas Basin is very important for the evaluation of radiogenic versus mantle helium input.

For the Gulf of California this injected helium is a relatively small component superimposed upon the dissolved atmospheric and deep Pacific background helium, and any estimate of the ${ }^{3} \mathrm{He} /{ }^{4} \mathrm{He}$ ratio of the injected fraction requires very accurate measurements of both the ${ }^{3} \mathrm{He} /{ }^{4} \mathrm{He}$ ratio and the absolute $\mathrm{He}$ concentrations in the water. Isotope dilution measurements of absolute helium and neon concentrations have been made for the Guaymas and Mazatlan basin profiles. These results are listed in Table 2 as $\Delta\left({ }^{3} \mathrm{He} / \mathrm{Ne}\right){ }^{\prime}$ and $\Delta\left({ }^{4} \mathrm{He} / \mathrm{Ne}\right)$, which are the percentage deviations of ${ }^{3} \mathrm{He} / \mathrm{Ne}$ and ${ }^{4} \mathrm{He} / \mathrm{Ne}$ from the solubility ratios. Thus

$$
\left.\Delta\left(\frac{{ }^{3} \mathrm{He}}{\mathrm{Ne}}\right) \%=\mid \frac{\mathrm{C}\left({ }^{3} \mathrm{He}\right) / \mathrm{S}\left({ }^{3} \mathrm{He}\right)}{\mathrm{C}(\mathrm{Ne}) / \mathrm{S}(\mathrm{Ne})}-1\right\rfloor \times 100
$$

where $C(x)$ is the measured concentration of species $x$, and $S(x)$ is the expected concentration for air saturated water at the potential temperature and salinity of the sample. Because neon in these samples is essentially entirely of atmospheric origin, $\Delta\left({ }^{3} \mathrm{He} / \mathrm{Ne}\right)$ and $\Delta\left({ }^{4} \mathrm{He} / \mathrm{Ne}\right)$ are sensitive indicators of the absolute excesses of ${ }^{3} \mathrm{He}$ and ${ }^{4} \mathrm{He}$ above the dissolved atmospheric component. As shown in Table 2, the deep Guaymas Basin is $\sim 92 \%$ enriched in absolute ${ }^{3} \mathrm{He}$ concentration and $\sim 12 \%$ enriched in ${ }^{4} \mathrm{He}$ concentration.

The ${ }^{3} \mathrm{He} /{ }^{4} \mathrm{He}$ ratio of the actual injected helium is probably best determined from the slope of $\Delta\left({ }^{3} \mathrm{He} / \mathrm{Ne}\right)$ versus $\Delta\left({ }^{4} \mathrm{He} / \mathrm{Ne}\right)$. This technique normalizes the results to neon and, to first order, eliminates errors in sample weight, variations in original atmospheric components, etc. In Figure $6, \Delta\left({ }^{3} \mathrm{He} / \mathrm{Ne}\right)$ is plotted versus $\Delta\left({ }^{4} \mathrm{He} / \mathrm{Ne}\right)$ for the Guaymas Basin (H29) and Mazatlan Basin (FD4) and for the Galapagos Rift Deep-Tow samples. The Galapagos results provide comparison with the only other open-ocean submarine hydrothermal system in which mantle-type helium has been detected. Although ${ }^{3} \mathrm{He} /{ }^{4} \mathrm{He}$ ratios and approximate ${ }^{4} \mathrm{He}$ amounts for these Galapagos samples were reported previously [Lupton et al., 1977b], this is the first discussion of the high-precision isotope dilution measurements of absolute helium and neon concentrations for these samples (see Table 3).

As shown in Figure 6, both the Guaymas Basin and Galapagos Rift samples plot on a line of slope 8.0, indicating that the 


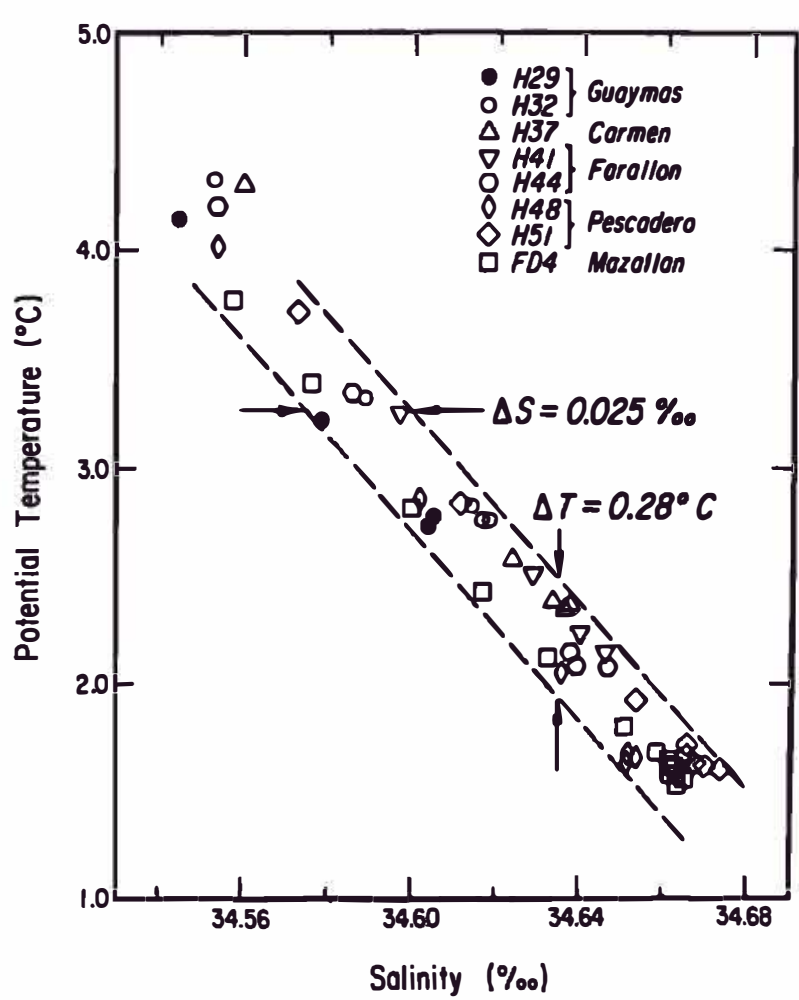

Fig. 5. Potential temperature versus salınity for eight hydrographic stations in the Gulf. At depths below $1500 \mathrm{~m}$ the data all fall within a band $0.28^{\circ} \mathrm{C}$ wide, which probably represents errors in the salinity data of $\pm 0.025 \%$. Within these broad limits, there is no evidence for geothermal heating correlated with the observed ${ }^{3} \mathrm{He}$ enrichments.

injected helium in both these localities has an isotopic ratio 8 times the atmospheric ratio, a very clear confirmation of the mantle origin of this helium. Separate linear regression fits to the data give slopes of $7.84 \pm 0.40$ for the Guaymas Basin and $8.16 \pm 0.22$ for the Galapagos samples (errors are $2 \sigma$ ), indicating that estimates of the ${ }^{3} \mathrm{He} /{ }^{4} \mathrm{He}$ ratios from these two areas agree within precision estimates. A fit to the Mazatlan Basin profile alone has a distinctly lower slope of $6.95 \pm 0.72$, which may be characteristic of general oceanic injection as opposed to a specific hydrothermal system. Note that Jenkins et al. [1978] found ${ }^{3} \mathrm{He} /{ }^{4} \mathrm{He}=(1.08 \pm 0.02) \times 10^{-5}$ for a suite of hydrothermal waters collected at the Galapagos Rift using ALVIN, in agreement with my estimate.

In order to estimate the ${ }^{3} \mathrm{He} /{ }^{4} \mathrm{He}$ ratio of the injected helium for the Gulf of California samples, I have compared the concentrations of ${ }^{3} \mathrm{He},{ }^{4} \mathrm{He}$, and $\mathrm{Ne}$ in deep versus shallow samples. This procedure may be inaccurate because the shallow waters have a different origin from the deep samples and have therefore undergone different histories in terms of temperature, atmospheric pressure, air injection, etc. That is, the shallow waters do not represent the input or ambient water for the entire profile before the addition of the anomalous helium. Although in principle it is possible to correct for this effect using additional stable conservative gases (e.g., $\mathrm{Ar}, \mathrm{N}_{2}$, etc.), these data are not available for the samples discussed here. However, for the Galapagos samples, which were all deep collections, the normal bottom waters do accurately represent the input water before helium addition, and the above concern does not apply. The fact that the Galapagos and Guaymas Basin helium isotope ratios are indistinguishable supports the conclusion that this ratio of 8 times atmospheric is typical for spreading center hydrothermal systems in general.

The best estimate for the Guaymas Basin injected helium is ${ }^{3} \mathrm{He} /{ }^{4} \mathrm{He}=(1.10 \pm 0.06) \times 10^{-5}$, some $20 \%$ lower than the average for helium contained in the glassy rims of oceanic basalts from worldwide localities. If this helium is derived from spreading center basalts, then one must explain this significant difference in the helium isotopic signatures. One explanation is simply that Guaymas Basin basalts contain helium with an isotopic ratio lower than the global average. Although no helium isotope results are available for Guaymas Basin basalts, a recent measurement in this laboratory of a Galapagos Rift basalt glass gave ${ }^{3} \mathrm{He} /{ }^{4} \mathrm{He}=1.19 \times 10^{-5}$ (R. Poreda, personal communication, 1979), one example of a spreading center basalt with lower than average ${ }^{3} \mathrm{He} /{ }^{4} \mathrm{He}$. Another explanation for the discrepancy is that while the basalt glass represents the pure upper mantle component, the helium formed in submarine hydrothermal systems is a mixture of this mantle component with radiogenic helium derived from $\mathrm{U}$ and $\mathrm{Th}$ in both the basalts and the overlying sediments. If this is the case, one would expect significant variations in the ${ }^{3} \mathrm{He} /{ }^{4} \mathrm{He}$ signatures of hydrothermal waters depending on the relative strengths of the mantle and radiogenic inputs, and it is difficult to explain why the Guaymas Basin and the Galapagos Rift have identical helium signatures. However, results for the Mazatlan Basin $\left({ }^{3} \mathrm{He} /{ }^{4} \mathrm{He}=9.7 \times 10^{-6}\right)$ and for the Red Sea Brines $\left({ }^{3} \mathrm{He} /{ }^{4} \mathrm{He}=1.20 \times 10^{-5}\right)$ indicate that helium injected into the deep oceans does exhibit some isotopic variability. The question of the variability of ${ }^{3} \mathrm{He} /{ }^{4} \mathrm{He}$ at different injection sites must remain unanswered until additional studies of ridge-crest hydrothermal systems are completed.

\section{SUMmARY AND CONCLUSIONS}

The results of this helium isotope study of the Gulf of California can be summarized as follows:

1. The water at 1600 to $1900-\mathrm{m}$ depth in the Guaymas Basin contains dissolved helium $68 \%$ enriched in ${ }^{3} \mathrm{He} /{ }^{4} \mathrm{He}$ relative to atmospheric helium. The absolute concentrations of ${ }^{3} \mathrm{He}$ and ${ }^{4} \mathrm{He}$ in this water are respectively $92 \%$ and $12 \%$ enriched relative to air solubility. The presence of this anomalous helium component indicates that mantle volatiles are being injected into the deep Guaymas Basin, associated with extensional effects and formation of new oceanic crust. The helium isolopes thus provide direct evidence for an active spreading center in the Guaymas Basin.

2. In addition to the Guaymas Basin, the Carmen and Farallon basins also show ${ }^{3} \mathrm{He}$ excesses relative to average eastern Pacific deep water. However, careful inspection of the controlling bathymetry shows that the excess ${ }^{3} \mathrm{He}$ in these basins may well originate in the Guaymas Basin.

3. The absence of any large ${ }^{3} \mathrm{He}$ excess in the Mazatlan Basin profile relative to average eastern Pacific profiles implies that the

TABLE 3. Helium and Neon Isolopic Data for Galapagos Rift Deep-Tow Samples

\begin{tabular}{|c|c|c|c|}
\hline Sample No.* & $\begin{array}{c}\delta\left({ }^{3} \mathrm{He}\right) \\
\%\end{array}$ & $\underset{\% / 0}{\Delta\left({ }^{3} \mathrm{He} / \mathrm{Ne}\right)}$ & $\Delta \underset{\%}{\Delta\left({ }^{4} \mathrm{He} / \mathrm{Ne}\right)}$, \\
\hline \multicolumn{4}{|c|}{ Hydrothermal Plumes } \\
\hline $7-0$ & 99.3 & 137.7 & 17.6 \\
\hline $8-3$ & 35.7 & 46.2 & 6.2 \\
\hline $8-6$ & 42.6 & 55.8 & 7.7 \\
\hline \multicolumn{4}{|c|}{ Normal Bottom Waters } \\
\hline $7-1$ & 27.8 & 36.6 & 5.4 \\
\hline $8-1$ & 28.6 & 37.6 & 5.5 \\
\hline $8-2$ & 30.2 & 39.3 & 5.5 \\
\hline $8-5$ & 33.4 & 43.3 & 5.9 \\
\hline $8-7$ & 32.3 & 41.9 & 5.8 \\
\hline
\end{tabular}

The $1 \sigma$ error in the analytical precision is $0.7 \%$ for $\delta\left({ }^{3} \mathrm{He}\right)$ and $0.3 \%$ for $\Delta\left({ }^{3} \mathrm{He} / \mathrm{Ne}\right)$ and $\Delta\left({ }^{4} \mathrm{He} / \mathrm{Ne}\right)$.

"Tow number, bottle number. Positions are given in a previous paper [Weiss et al., 1977]. 


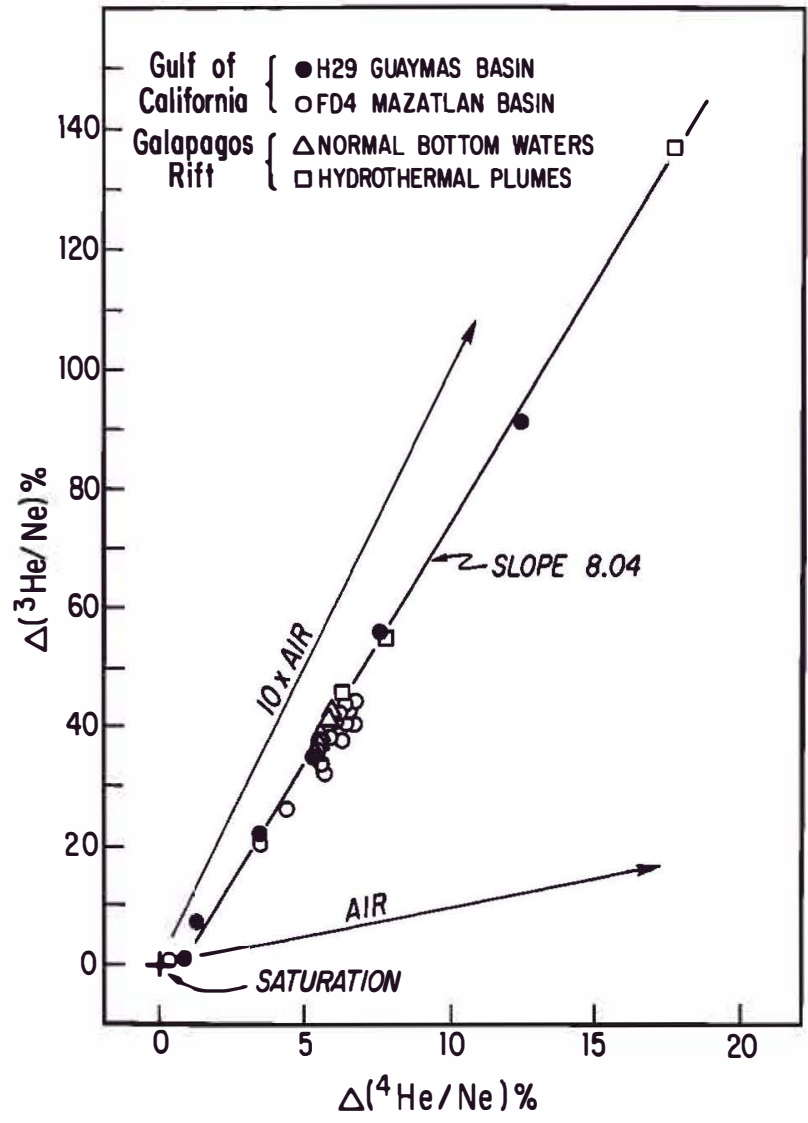

Fig. $6 \Delta\left({ }^{3} \mathrm{He} / \mathrm{Ne}\right)$ versus $\Delta\left({ }^{4} \mathrm{He} / \mathrm{Ne}\right)$ for Guaymas and Mazatlan basin samples and for hydrothermal plume and background water samples collected with Deep-Tow on the Galapagos Rift [Weiss et al., 1977; Lupton et al., 1977b]. The Guaymas Basin and Galapagos samples fall on a line of slope 8.0, corresponding to injection of helium with ${ }^{3} \mathrm{He} /{ }^{4} \mathrm{He}=1.1 \times 10^{-5}$ (8 times the atmospheric ratio) in these areas.

Gulf of California does not provide significant input of ${ }^{3} \mathrm{He}$ into the general Pacific circulation.

4. The hydrographic data show that any geothermal heating which has occurred must have a magnitude $<0.28^{\circ} \mathrm{C}$. Positive temperature anomalies of $0.03^{\circ}-0.10^{\circ} \mathrm{C}$ would be expected for the Guaymas Basin based on the measured ${ }^{3} \mathrm{He}$ excess.

5. The covariation of ${ }^{3} \mathrm{He}$ and ${ }^{4} \mathrm{He}$ concentrations relative to neon indicate that the injected helium in the deep Guaymas Basin has ${ }^{3} \mathrm{He} /{ }^{4} \mathrm{He}=1.1 \times 10^{-5}$, identical to the helium found in submarine vents at the Galapagos Rift. This elevated ${ }^{3} \mathrm{He} /{ }^{4} \mathrm{He}$ ratio clearly implies a mantle origin for this helium, although the ratio is somewhat lower than the global average for submarine basalt glasses.

Acknowledgments. I wish to thank $\mathrm{H}$. Craig for his valuable input into all aspects of this work. L. Cunningham, M. Waldorf, G. Sharman, and chief scientist P. Wilde collected the samples on leg 2 of Hypogene Expedition. D. Bos, J. Jain, and J. Schmilt assisted with the F Drake 77 collections, in which F. Spiess and K. Macdonald were chief scientists. R. Weiss provided the Galapagos Rift samples. The late A. E. Bainbridge deserves special recognition for providing the hydrographic data and for discussions of accuracy of the temperature and salinity measurements. A. Birket and L. Wetherell performed most of the laboratory analyses reported here, and E. Hernandez and H. Kueker were responsible for the maintenance of the vacuum lines and mass spectrometers. R. Michel and R. Poreda kindly made their unpublished results available. This work was supported by a grant from the National Science Foundation.

\section{REFERENCES}

Clarke, W. B., M. A. Beg, and H. Craig, Excess ${ }^{3} \mathrm{He}$ in the sea: Evidence for terrestrial primordial helium, Earth Planet. Sci. Lett., 6, 213, 1969.

Clarke, W. B., M. A. Beg, and H. Craig, Excess helium-3 at the North Pacific Geosecs station, J. Geophys. Res., 75, 7676, 1970.

Clarke, W. B., W. J. Jenkıns, and Z. Top, Determınation of tritium by mass spectrometric measurement of ${ }^{3} \mathrm{He}$, Int. J. Appl. Radiat. Isotopes, 27, 515, 1976.

Craig, H., and D. Lal, The production rate of natural tritium, Tellus, 13, 85, 1961.

Craig, H., and J. E. Lupton, Primordial neon, helium, and hydrogen in oceanic basalts, Earth Planet. Sci. Lett., 31, 369, 1976.

Craig, H., W. B. Clarke, and M. A. Beg, Excess ${ }^{3} \mathrm{He}$ in deep water on the East Pacific Rise, Earth Planet. Sci. Lett., 26, 125, 1975.

Craig, H., J. E. Lupton, and Y. Horibe, A mantle helium component in Circum-Pacific volcanic gases: Hakone, the Marianas and Mt. Lassen, Advan. Earth Planet. Sci., 3, 3, 1978a.

Craig, H., J. E. Lupton, J. A. Welhan, and R. Poreda, Helium isotope ratios in Yellowstone and Lassen Park volcanic gases, Geophys. Res. Lett., 5, 897, 1978b.

Fine, R. A., and H. G. Östlund, Source function for tritium transport models in the Pacific, Geophys. Res. Lett., 4, 461, 1977.

Fisher, R. L., G. A. Rusnak, and F. P. Shepard, Submarine topography of the Gulf of California, Chart I, in Marine Geology of the Gulf of California, American Association of Petroleum Geologists, Tulsa, Okla., 1964.

Jenkins, W. J., and W. B. Clarke, The distribution of ${ }^{3} \mathrm{He}$ in the western Allantic ocean, Deep Sea Res., 23, 481, 1976.

Jenkins, W. J., J. M. Edmond, and J. B. Corliss, Excess ${ }^{3} \mathrm{He}$ and ${ }^{4} \mathrm{He}$ in Galapagos submarine hydrothermal waters, Nature, 272, 156, 1978.

Kaufman, S., and W. F. Libby, The natural distribution of tritium, Phys. Rev., 93, 1337, 1954.

Larson, R. L., H. W. Menard, and S. M. Smith, Gulf of California: A result of ocean-floor spreading and transform faultıng, Science, 161, $781,1968$.

Larson, P. A., J. D. Mudie, and R. L. Larson, Magnetic anomalies and fracture-zone trends in the Gulf of California, Geol. Soc. Amer. Bull., 83, 3361, 1972.

Lawver, L. A., J. G. Sclater, T. L. Henyey, and J. Rogers, Heat flow measurements in the southern portion of the Gulf of Californa, Earth Planet. Sci. Lett., 12, 198, 1973.

Lawver, L. A., D. L. Williams, and R. P. Von Herzen, A major geothermal anomaly in the Gulf of California, Nature, 257, 23, 1975.

Lupton, J. E., The ${ }^{3} \mathrm{He}$ distribution in deep water over the Mid-Atlantic Ridge, Earth Planet. Scı. Lett., 32, 371, 1976.

Lupton, J. E., and $\mathrm{H}$. Craig, Excess ${ }^{3} \mathrm{He}$ in oceanic basalts: Evidence for terrestrial primordial helium, Earth Planet. Sci. Lett., 26, 133, 1975.

Lupton, J. E., R. F. Weiss, and H. Craig, Mantle helium in the Red Sea Brines, Nature, 266, 244, 1977a.

Lupton, J. E., R. F. Weiss, and H. Craig, Mantle helium in hydrothermal plumes in the Galapagos Rift, Nature, 267,603, 1977b.

Polak, B. G., V. I. Kononov, I. N. Tolstikhin, B. A. Mamyrin, and L. V. Khabarin, The helium isotopes in thermal fluids, Int. Ass. Hydrol. Sci. Publ., 119, 17, 1976.

Roden, G. I., Oceanographic aspects of the Gulf of California, Marine Geology of the Gulf of California, American Association of Petroleum Geologists, Tulsa, Okla., p. 126, 1964.

von Butllar, N., and W. F. Libby, Natural distribution of cosmic-ray produced trıtium, J. Inorg. Nucl. Chem., I, 75, 1955.

Von Herzen, R. P., Geothermal heat flow in the Gulfs of California and Aden, Science, 140, 1207, 1963

Weiss, R. F., P. F. Lonsdale, J. E. Lupton, A. E. Bainbridge, and H. Craig, Hydrothermal plumes in the Galapagos Rift, Nature, 267, 600, 1977.

Wilde, P., H. W. Menard, and G. Sharman, Temperature-salinity-depth profiles from deeps in the Gulf of California, Eos Trans. AGU, 54, $322,1973$.

(Received June 20, 1979; revised September 26, 1979; accepted October 4, 1979.) 